\title{
Antibacterial and phytochemical analysis of Banana fruit peel
}

\author{
*Ehiowemwenguan, G., ${ }^{1}{ }^{*}$ Emoghene, A. O. ${ }^{1}$ and $*$ Inetianbor, J.E. ${ }^{2}$ \\ ${ }^{I}$ Department of Microbiology, University of Benin, P.M.B. 1154, Benin City, Nigeria \\ ${ }^{2}$ Department of Microbiology, Federal University, Wukari, P.M.B 1020, Taraba State, Nigeria
}

\begin{abstract}
The in vitro antibacterial activity of ethanolic and aqueous extract of banana (Musa sapientum) peels was investigated on both gram-positive and gram-negative bacteria using agar well diffusion technique . The ethanolic extract of the peels had MIC values ranging from $16 \mathrm{mg} / \mathrm{ml}$ to $512.5 \mathrm{mg} / \mathrm{ml}$. The least MIC was $16 \mathrm{mg} / \mathrm{ml}$ against Salmonella typhi while Bacillus subtilis and Staphylococcus aureus showed the highest MIC of $512.5 \mathrm{mg} / \mathrm{ml}$. In the aqueous extract the MIC ranged between $512.5 \mathrm{mg} / \mathrm{ml}$ to $>1025 \mathrm{mg} / \mathrm{ml}$. Salmonella typhi, Micrococcus luteus and Staphylococcus aureus were not inhibited by the water extract. Phytochemical result showed ethanol to be a better solvent for the extraction of the bioactive agents in banana peels which include: glycosides, alkaloids, saponins, tannins, flavonoids and volatile oil.
\end{abstract}

KEYWORDS: Antibacterial qualities, Phytochemicals, Banana (Musa sapientum).

\section{INTRODUCTON}

Banana is a tropical fruit grown in over 122 countries worldwide (Husain and William, 2010). Until 2004, the cultivated area of 3.8 million hectares and a total production of 56.4 million metric tones of the fruit were produced ranking it fourth behind rice, corn and milk (Chai et al., 2004; Arumugam and Manikandan, 2011). In recent times, Banana peel has been utilized for various industrial applications including bio-fuel production, bio-sorbents, pulp and paper, cosmetics, energy related activities, organic fertilizer, environmental clean up and biotechnology related processes (Morton, 1987; Gunaseelan, 2004; Bori et al., 2007).

Bananas are naturally slightly radioactive, more so than most other fruits, because of their potassium content and the small amounts of the isotope potassium- 40 found in naturally occurring potassium (Amarnath and Balakrishnan, 2007).

Ripe bananas fluoresce when exposed to ultraviolet light. The study suggested that this allows animals which can see light in the ultraviolet spectrum (tetrachromats and pentachromats) to more easily detect ripened bananas (Ashraf et al., 2010). This property is attributed to the degradation of chlorophyll leading to the accumulation of a fluorescent product in the skin of the fruit. The chlorophyll breakdown product is stabilized by a propionate ester group (Anhwange et al., 2009). Banana-plant leaves also fluoresce in the same way (Ashraf et al., 2010). Green bananas do not fluoresce (Bhat et al., 2010 ).

All parts of the banana plant have medicinal applications (Amit and Shailandra, 2006): the flowers in bronchitis and dysentery and on ulcers; cooked flowers are given to diabetics; the astringent plant sap in cases of hysteria, epilepsy, leprosy, fevers, hemorrhages, acute dysentery and diarrhea, and it is applied on hemorrhoids, insect and other stings and bites; young leaves are placed as poultices on burns and other skin afflictions; the astringent ashes of the unripe peel and of the leaves are taken in dysentery and diarrhea and used for treating malignant ulcers (Girish and Satish, 2008); the roots are administered in digestive disorders, dysentery and other ailments; banana seed mucilage is given in cases of diarrhea in India (Bhat et al., 2010 a).

Antifungal and antibiotic principles are found in the peel and pulp of fully ripe bananas (Brooks, 2008). The antibiotic acts against Mycobacteria (Omojasola and Jilani, 2009). A fungicide in the peel and pulp of green fruits is active against a fungus disease of tomato plants (Ponnuswamy et al., 2011). Norepinephrine, dopamine, and serotonin are also present in the ripe peel and pulp (Ratule et al., 2007). The first two elevate blood pressure; serotonin inhibits gastric secretion and stimulates the smooth muscle of the intestines (Anhwang et al., 2009).

Some of the specific diseases known to be cured by banana are Anaemia: High in iron, bananas are believed to stimulate the production of haemoglobin in the blood and so helps in cases of anaemia (Amit and Shailandra, 2006). Blood Pressure: Banana is extremely high in potassium yet low in salt, making it the perfect food for helping to beat blood pressure (Debabandya et al., 2010). Depression: This is because bananas contain tryptophan, a type of protein that the body converts into serotonin known to make you relax, improve your mood and generally make you feel happier (Girish and Satish, 2008). Heartburn: Bananas have a natural antacid 
effect in the body so if you suffer from heartburn, try eating a banana for soothing relief (Mokbel et al., 2005). Morning Sickness: Snacking on bananas between meals helps to keep blood sugar levels up and avoid morning sickness (Amit and Shailandra, 2006). Mosquito bites: Before reaching for the insect bite cream, try rubbing the affected area with the inside of a banana skin. Many people find it amazingly successful at reducing swelling and irritation (Odebiyi and Sofowora, 1978). Nerves: Bananas are high in B vitamins that help calm the nervous system (Singh and Bhat, 2003). Smoking: Bananas can also help people trying to give up smoking, as the high levels of Vitamin C, A1, B6, B12 they contain, as well as the potassium and magnesium found in them, help the body recover from the effects of nicotine withdrawal (Mokbel et al., 2005). Stress: Potassium is a vital mineral, which helps normalize the heartbeat, sends oxygen to the brain and regulates the body's water-balance (Girish and Satish, 2008).

Strokes: eating bananas as part of a regular diet can cut the risk of death by strokes by as much as $40 \%$ (Amit and Shailandra, 2006). Temperature control: Many other cultures see bananas as a cooling fruit that can lower both the physical and emotional temperature of expectant mothers (Mokbel et al., 2005). Ulcers: The banana is used as the dietary food against intestinal disorders because of its soft texture and smoothness (Girish and Satish, 2008). And Warts: Those keen on natural alternatives swear that, if you want to kill off a wart, take a piece of banana skin and place it on the wart, with the yellow side out (Amit and Shailandra, 2006).

Alleged hallucinogenic effects of the smoke of burning banana peel have been investigated scientifically and have not been confirmed (Anhwange et al., 2009).

It has been observed that antimicrobial activity of the plants is associated with the presence of some chemical components such as phenols, tannis, saponins, alkaloids, steroids, flavonoids and carbohydrates (Singh and Bhat, 2003).

This study is aimed at investigating the antibacterial activity and phytochemical properties of Banana fruit (Musa sapientum) Peels on some bacterial isolates

\section{MATERIALS AND METHODS}

\section{Sample Collection and Preparation}

The banana peels used for the investigation were obtained from bananas bought from Uselu market, Benin City, Nigeria. They were air-dried for two weeks and ground into powder with a mechanical blender and sieved with a mesh of size $0.50 \mathrm{~mm}$. The powdered samples obtained were thereafter stored in clean brown bottles at room temperature $\left(28 \pm 2^{\mathrm{O}} \mathrm{C}\right)$ until needed for use.

\section{Preparation of Aqueous and Ethanol Extract}

Ninety (90) grams of the powdered peels was dispensed in $900 \mathrm{ml}$ of distilled water in a 1L capacity conical flask. The mixture was stirred vigorously intermitently with a magnetic stirrer and then allowed to stand for $48 \mathrm{~h}$. It was stirred again and filtered through a Whatman filter paper lined funnel into a conical flask. The filtrate was evaporated at $40^{\circ} \mathrm{C}$ with a water bath to obtain the solid crude extract.

The same procedure was carried out for ethanol extraction except that the crude solid extract was obtained by concentrating the filtrate with a rotary evaporator. All extracts obtained were stored in a refrigerator until required for use.

\section{Phytochemical Analysis}

The extracts of Musa sapientum peels were analysed for alkanoids, tannins, glycosides, steroids, flavonoids, saponins, volatile oil and resins using standard procedures.

Test for Glycosides: To $1 \mathrm{ml}$ of the extract was added $2 \mathrm{ml}$ of acetic acid and then cooled in an ice bath at $4{ }^{\mathrm{O}} \mathrm{C}$. To this mixture $1 \mathrm{ml}$ of concentrated tetraoxosulphate (vi) acid $\left(\mathrm{H}_{2} \mathrm{SO}_{4}\right)$ was added dropwise. The formation of an oil layer on top of solution indicated the presence of glycosides (Odebiyi and Sofowora, 1978).

Test for Alkaloides: To $3 \mathrm{ml}$ of the extract was added $1 \mathrm{ml}$ of $1 \%$ HCL. This resulting mixture was then treated with few drops of Meyer's reagent. The appearance of a creamy white precipitate confirmed the presence of alkaloids (Ogukwe et al., 2004).

Test for Saponins: Five drops of olive oil was added to $2 \mathrm{ml}$ of the plant extract and the mixture shaken vigorously. The formation of a stable emulsion indicated the presence of saponins (Trease and Evans, 1996)

Test for Tannins: Two drops of $5 \% \mathrm{FeCl}_{3}$ was added to $1 \mathrm{ml}$ of the plant extract. The appearance of a dirtygreen precipitate indicated the presence of tannins (Trease and Evans, 1996)

Test for Flavonoids: To $1 \mathrm{ml}$ of the extract was added 3 drops of ammonia solution $\left(\mathrm{NH}_{3}{ }^{+}\right)$followed by $0.5 \mathrm{ml}$ of concentrated $\mathrm{HCl}$. The resultant pale brown colouration of the entire mixture indicated the presence of flavonoids (Odebiyi and Sofowora, 1978). 
Test for Steroids: To $1 \mathrm{ml}$ of the plant extract was added $1 \mathrm{ml}$ of concentrated tetraoxosulphate (vi) acid $\left(\mathrm{H}_{2} \mathrm{SO}_{4}\right)$. A red colouration confirmed the presence of steroids (Trease and Evans, 1996).

Test for Resins: To $5 \mathrm{ml}$ of the extract was added $5 \mathrm{ml}$ of copper acetate solution. The mixture was shaken vigorously and allowed to separate. The appearance of a reddish-brown precipitate indicated the presence of resins (Elmahmood and Doughari, 2008).

\section{Source of Test Microorganisms}

Pure cultures of pathogenic bacteria such as Bacillus subtilis, Staphylococcus aureus, Micrococcus leutus, Klebsiella Pneumoniae, Pseudomonas aeruginosa, Escherichia coli and Salmonella typhi were obtained from the Department of Medical Microbiology, University of Benin, Teaching Hospital (UBTH), Benin City, Nigeria. They were gram stained and subjected to biochemical tests to confirm their identity (Cheesbrough, 2000). The organisms were subcultured in nutrient agar plates and stored in nutrient agar slants at $4^{\circ} \mathrm{C}$ until needed for use.

\section{Antibacterial Activity Assay}

The determination of antibacterial activity was done using the agar well diffusion technique (Cheesebrough, 2000).The organism to be tested was inoculated into sterile nutrient agar. After incubation period of $24 \mathrm{~h}$ at $37^{\circ} \mathrm{C}$, a loop of inoculum was transferred into $5 \mathrm{ml}$ of nutrient broth, incubated for $2 \mathrm{~h}$ at $37^{\circ} \mathrm{C}$. This served as fresh suspension inoculum. Wells $(5 \mathrm{~mm}$ diameter) were made in sterile nutrient agar plate using a sterile cork borer (flame sterilized) and inoculum containing $10^{7} \mathrm{CFU} / \mathrm{ml}$ of test bacteria were spread on solid plates with the aid of sterile swab moistened with the bacterial suspension. Then $50 \mu$ l of aqueous extract or ethanol extract of banana peels were placed in the wells made in inoculated plates. Controls were set up with $50 \mu \mathrm{l}$ of sterile distilled water or ethanol. The plates were incubated at $37^{\circ} \mathrm{C}$ for $24 \mathrm{~h}$ and zones of inhibition if any around the well were evaluated in millimeters (mm) (Girish and Satish, 2008).

\section{DETERMINATION OF MINIMUM INHIBITORY CONCENTRATIONS (MICs)}

Determination of the minimum inhibitory concentration (MIC) of the extracts was carried out using the tube-dilution technique described by Cheesebrough (2000). A double fold serial dilution was made using Muller Hinton broth (MHB).The following concentrations were obtained: $1025 \mathrm{mg} / \mathrm{ml}, 512.5 \mathrm{mg} / \mathrm{ml}, 256 \mathrm{mg} / \mathrm{ml}$, $128 \mathrm{mg} / \mathrm{ml}, 64 \mathrm{mg} / \mathrm{ml}, 32 \mathrm{mg} / \mathrm{ml}, 16 \mathrm{mg} / \mathrm{ml}$ and $8 \mathrm{mg} / \mathrm{ml}$. Equal volume of extract and Muller Hinton broth $(2 \mathrm{ml})$ was dispensed into sterilized test tubes. A quantity $(0.1 \mathrm{ml})$ of standardized inoculum $\left(1.25 \times 10^{7} \mathrm{cfu} / \mathrm{ml}\right)$ was added to each of the test tubes which were incubated aerobically at $37^{\circ} \mathrm{C}$ for each $24 \mathrm{~h}$. A tube containing broth and inoculum without extract served as organism control. The tube with broth and extract without inoculum served as extract control. The lowest concentration of the extracts which inhibited microbial growth (no turbidity) was recorded as the minimum inhibitory concentration(MIC).

\section{DETERMINATION OF MINIMUM BACTERICIDAL CONCENTRATION. (MBC)}

Sterile Muller Hinton agar plates were inoculated with samples from each of the test tubes that showed no visible growth from the MIC test. The plates were then incubated at $37^{\circ} \mathrm{C}$ for $24 \mathrm{~h}$. The lowest concentration of the extract yielding no growth was recorded as the minimum bactericidal concentration (MBC).

\section{RESULTS}

\section{PHYTOCHEMICAL PROPERTIES OF Musa sapientum Peels}

The different phytochemical constituents present in the peels of Musa sapientum is shown in Table 1. It was observed that different phytoconstituents have different degrees of solubility in different types of solvents depending on their polarity. In the ethanol extract, the phytochemicals present include : alkaloids, glycosides, saponins, tannins and flavonoids. Of the phytochemicals assayed for, only two: glycosoides and alkaloids where found in the water extract (Table 1).

\section{ANTIBACTERIAL ACTIVITY OF EXTRACTS OF Musa sapientum Peels}

The results of the antibacterial activity of the aqueous and ethanolic extracts of Musa sapientum peels against the test organisms are shown in Tables 2,3, and 4. The zone of inhibition of the growth of the isolates was found to be a function of the relative antibacterial potency of the extracts. Thus zones of inhibition decreased as the concentration of the extracts decreased.(Tables 2 and 3). At a concentration of $1025 \mathrm{mg} / \mathrm{ml}$, the highest zone of clearance was obtained from ethanol extract against Klebsiella pnuemoniae with a diameter of $38 \mathrm{~mm}$. This was followed by Pseudomonas aeruginosa $(33 \mathrm{~mm})$, Salmonella typhi $(30 \mathrm{~mm})$ and Escherichia coli $(26 \mathrm{~mm})$ respectively. The lowest zone of inhibition at this concentration was $8 \mathrm{~mm}$ against Staphylococcus aureus. 
Higher growth inhibition was obtained with the ethanol extract compared with aqueous extracts. In table 3 the antibacterial activity of the aqueous extract of Musa sapientum peels revealed the highest zone of inhibition to be $24 \mathrm{~mm}$ against klebsiella pnuemoniae compared to $38 \mathrm{~mm}$ of ethanolic extract at the same concentration (1025mg/ml). The bacteria Staphylococcus aureus, Micrococcus leutus, and Salmonells typhi were not inhibited with the water extract and thus showed no zone of inhibition. The lowest zone of clearance in this experiment was $2 \mathrm{~mm}$ against Escherichia coli using water extract at a concentration of $64 \mathrm{mg} / \mathrm{ml}$.

In table 4 is shown the results of the minimum inhibitory concentration (MIC) and minimum bactericidal concentration (MBC) of Musa sapientum peels on the test bacteria. The ethanolic extract of the peels had MIC values ranging from $16 \mathrm{mg} / \mathrm{ml}$ to $512.5 \mathrm{mg} / \mathrm{ml}$. The least MIC was $16 \mathrm{mg} / \mathrm{ml}$ against Salmonella typhi while Bacillus subtilis and Staphylococcus aureus showed the highest MIC of $512.5 \mathrm{mg} / \mathrm{ml}$. The MBC values of the ethanol extract ranged between $32 \mathrm{mg} / \mathrm{ml}$ to $>1025 \mathrm{mg} / \mathrm{ml}$. The MIC and MBC values of the aqueous extract ranged between $0-1025 \mathrm{mg} / \mathrm{ml}$ and 0 to $>1025 \mathrm{mg} / \mathrm{ml}$ respectively.In the water extract Escherichia coli showed the least MIC of $64 \mathrm{mg} / \mathrm{ml}$ and the highest was $1025 \mathrm{mg} / \mathrm{ml}$ against Bacillus cereus.

Table 1: Phytochemical characteristics of the whole extracts of Musa sapientum peels

\begin{tabular}{lccc}
\hline Phytochemical constituent & Ethanol Extract & Water Extract \\
\hline Glycosides & + & + & + \\
Alkaloids & + & - & - \\
Saponins & + & - \\
Steroids & + & - \\
Tannins & + & - \\
Flavonoids & - & - \\
Resins & + & \\
Volatile oil & &
\end{tabular}

$+=$ present $\quad-=$ Absent. 
Table 2: The antibacterial activities of the ethanol extract of Musa sapientum peels. Zone of inhibition $(\mathrm{mm})$ of bacterial isolates

\begin{tabular}{lccccccc}
\hline $\begin{array}{l}\text { Conc. B1 } \\
(\mathrm{mg} / \mathrm{ml})\end{array}$ & B2 & B3 & B4 & B5 & B6 & B7 \\
\hline 1025 & 12 & 08 & 14 & 38 & 33 & 26 & 30 \\
512.5 & 08 & 05 & 10 & 34 & 28 & 23 & 24 \\
256 & 0 & 0 & 04 & 30 & 20 & 18 & 21 \\
128 & 0 & 0 & 0 & 26 & 15 & 12 & 16 \\
64 & 0 & 0 & 0 & 24 & 0 & 08 & 10 \\
32 & 0 & 0 & 0 & 10 & 0 & 0 & 08 \\
16 & 0 & 0 & 0 & 0 & 0 & 0 & 06 \\
8 & 0 & 0 & 0 & 0 & 0 & 0 & 0 \\
4 & 0 & 0 & 0 & 0 & 0 & 0 & 0 \\
\hline
\end{tabular}

\section{KEY}

$\mathrm{B} 1=$ Bacillus subtilis

B2=Staphylococcus aureus

B3=Micrococcus luteus

B4=Klebsiella pneumonia

B5=Pseudomonas aeruginosa

B6=Escherichia coli

B7=Salmonella typhi

Table 3: The antibacterial activities of water extract of Musa sapientum peels.

\section{Zone of inhibition ( $\mathrm{mm}$ ) of bacterial isolates}

\begin{tabular}{lccccccc}
\hline $\begin{array}{l}\text { Conc. } \\
(\mathrm{mg} / \mathrm{ml})\end{array}$ & B1 & B2 & B3 & B4 & B5 & B6 & B7 \\
\hline 1025 & 08 & 0 & 0 & 24 & 06 & 12 & 0 \\
512.5 & 0 & 0 & 0 & 18 & 04 & 08 & 0 \\
256 & 0 & 0 & 0 & 15 & 0 & 06 & 0 \\
128 & 0 & 0 & 0 & 12 & 0 & 04 & 0 \\
64 & 0 & 0 & 0 & 0 & 0 & 02 & 0 \\
32 & 0 & 0 & 0 & 0 & 0 & 0 & 0 \\
16 & 0 & 0 & 0 & 0 & 0 & 0 & 0 \\
8 & 0 & 0 & 0 & 0 & 0 & 0 & 0 \\
4 & 0 & 0 & 0 & 0 & 0 & 0 & 0 \\
\hline
\end{tabular}

KEY
B1=Bacillus subtilis
B2=Staphylococcus aureus
B3=Micrococcus luteus
B4=Klebsiella pneumonia 
B7=Salmonella typhi

Table 4: The Minimum Inhibitory and Bactericidal Concentrations of both Ethanol and Water extracts of Musa sapientum Peels on bacterial isolates

\begin{tabular}{llllll}
\hline & Isolates & Ethanol Extract & Water Extract & \\
\hline & & MIC & MBC & MIC & MBC \\
\hline B1 & Bacillus subtilis & 512.5 & $>1025$ & 1025 & $>1025$ \\
B2 & $\begin{array}{l}\text { Staphylococcus } \\
\text { aureus }\end{array}$ & 512.5 & $>1025$ & Nil & Nil \\
B3 & Micrococcus leutus & 256 & 256 & Nil & Nil \\
B4 & $\begin{array}{l}\text { Klebsiella } \\
\text { pneumonia } \\
\text { Pseudomonas } \\
\text { aeruginosa } \\
\text { Escherichia coli }\end{array}$ & 64 & 64 & 128 & 512 \\
B5 & Salmonella typhi & 16 & 128 & 512 & 1025 \\
B7 & 128 & 32 & 64 & 512 \\
\end{tabular}

KEY

$\mathrm{B} 1=$ Bacillus subtilis

B3=Micrococcus luteus

$\mathrm{B} 5=$ Pseudomonas aeruginosa

B7=Salmonella typhi

\section{B2=Staphylococcus aureus}

B4=Klebsiella pneumonia

B6=Escherichia coli

\section{DISCUSSION}

The preliminary phytochemical screening carried out showed Musa sapientum peels contain some secondary metabolites such as glycosides, alkaloids, saponins, volatile oil, flavonoids and tannins.

In general secondary metabolites present in plants have been reported by Rabe (2000) to be responsible for their therapeutic activity. Singh and Bhat (2003) reported that flavonoids are responsible for the antimicrobial activity associated with some ethnomedicinal plants.

Plant essential or volatile oils and their individual components have been used in traditional systems of medicines for a variety of bacterial infections for centuries. Furthermore, it has been demonstrated that antibacterial properties of these oils can be attributed to their hydrocarbon and terpene constituents (Amit and Shailendra, 2006). The presence of glycosides and alkaloids in Musa sapientum peels may be attributed to their use by traditional medicine practitioners in healthcare systems in the treatment of some bacterial infections such as cough, fever, cold and venereal diseases. The results of this research highlights the fact that the organic solvent (ethanol) extracts exhibited greater antimicrobial activity because the antimicrobial principles were either polar or non-polar and they were extracted more or only through the organic solvent medium. This observation agrees with the report of other investigators of medicinal plants that organic solvents are more suitable for extraction of phytochemicals. (Singh and Singh, 2000; Natarajan et al., 2005).

Microorganisms vary widely in their degree of susceptibility to anti-microbial agents. A high MIC value indicates low activity and vice versa. In this study the gram- negative organisms had the lowest MICs and MBCs. This suggest their higher susceptibility to the extract of the peels. On the basis of the result obtained in this investigation it can be conclude that ethanol extract of Musa sapientum peels had significant in vitro broad spectrum antimicrobial activity. Thus extracts from the plant can be used to control infections caused by Salmonella typhi, Escherichia coli, Klebsiella pneumoniae and Staphylococcus aureus. Opportunistic infections 
such as bronchopneumonia, bacterial endocarditis and meningitis caused by Micrococcus Spp. and Pseudomonas aeruginosa will also find treatment with the extracts of this medicinal peel. The results obtained in this study justify the use of banana peel by traditional medical practitioners.

\section{CONCLUSION}

Despite the significant progress made in microbiology and the control of microorganisms, sporadic incidents of epidemics due to drug resistant microorganisms pose an enormous threat to public health. The use of medicinal plants with antimicrobial activity need to be given more attention to arrest the situation.

\section{REFERENCES}

[1]. Aarti, D. and Anita, C. (2010). Utilization of banana peels and beet waste for alcohol production. Asiatic Journal of Biotechnological Research 1071: 8-13.

[2]. Aden, A., Ruth, M., Ibsen, K., Jechura J. and Neeves, K. (2002). Lignocellulosic biomass to ethanol process design and economics utilizing co-current dilute acid prehydrolysis and enzymatic hydrolysis for corn stover. Technical Report 7: 5-8.

[3]. Akinyele, B.J., Olaniyi, O. O. and Arotupin, D. J. (2011). Bioconversion of selected agricultural wastes and associated enzymes by Volvariella volvacea: An edible mushroom. Research Journal of Microbiology 6: 63-70.

[4]. Amarnath, R. and Balakrishnan, V. ( 2007). Evaluation of the banana (Musa paradisiaca) plant by-product's fermentation characteristics to asses their fodder potential. International Journal of Dairy Science 2: 217-225.

Amit, R and S, Shailandra (2006). Ethnomedicinal approach in biological and chemical investigation of phytochemicals as antimicrobials. Indian Journal of Pharmaceutical Science 41: 1-13.

[6]. Anhwange, B.A., Ugye ans, T. J. and Nyiaatagher, T. D. (2009). Chemical composition of Musa sapientum (Banana) peels. EJEAFChe. 8: 437-442.

[7]. Arotupin, D.J. ( 2007). Effect of different carbon sources on the growth and polygalacturonase activity of Aspergillus flavus isolated from cropped soils. Research Journal of Microbiology 2: 362-368.

[8]. Arumugam, R. and Manikandan, M. (2011). Fermentation of pretreated hydrolyzates of banana and mango fruit wastes for ethanol production. Asian Journal of Biological Science 2: 246-256.

[9]. Ashraf, M.A., Maa, M. J. and Yusoff, I. ( 2010). Study of banana peel (Musa Sepientum) as a cationic biosorbent. American and European Journal of Agricultural and Environmental Science 8: 7-17.

[10]. Bhat, M.S., Prabhakar, A., Rama, K. R. R., Madhu, G. M. and Rao, G. H. (2010). Statistical optimization and neural modeling of amylase production from banana peel using Bacillus subtilis MTCC 441. International Journal of Food Engineering 56: 34-45.

[11]. Bhat, M.S., Prabhakar, A., Rama, K.R.R. and Madhu, G. M. (2010). Optimization of process variables for amylase production using agro residual wastes by taguchi methodology. Chemistry of Production Processing Model 5: 4-7.

[12]. Bori, M.O., Adebusoye, S. A. Lawal, A. K. and Awotiwon, A. (2007). Production of biogas from banana and plantain peels. Advanced Environmental Biology 1: 33-38.

[13]. Brooks, A.A. (2008). Ethanol production potential of local yeast strains isolated from ripe banana peels. African Journal of Biotechnology 7: 3749-3752.

[14]. Chai, M., Ho, Y. W., Liew, K. W. and Asif, J.M. (2004). Biotechnology and in vitro Mutagenesis for Banana Improvement. In: Banana Improvement: Cellular, Molecular Biology and Induce Mutations, Jain, S. and R. Swennen (Eds.). Science Publisher Inc., USA., pp: 59-77.

[15]. Dashtban, M., Schraft, H. and Qin, W. (2009). Fungal bioconversion of lignocellulosic residues; opportunities and perspectives. International Journal of Biological Science 5: 578-595.

[16]. Debabandya, M., Sabyasachi, M. and Namrata, S. (2010). Banana and its by-products utilization: An overview of Journal of Science and Industrial Research 69: 323-329.

[17]. Dzomeku, B.M., Armo-Annor, F., Adjei-Gyan, K. and Darkey, S. K. (2007). Consumer preference for three selected Musa hybrids in Ghana. American Journal of Food Technology 2: 684-688.

[18]. Enwefa, C. (1991). Biomass production from banana skins. Applied Microbiology and Biotechnology 36: $283-284$

[19]. Essien, J.P., Akpan, E. J. and Essien, E. P. (2005). Studies on mould growth and biomass production using waste banana peel. Bioresource and Technology 96: 1451-1456.

[20]. FAO. (2009). FAOSTAT Statistics Database. Food and Agricultural Organization of the United Nations, Rome, Italy.

[21]. Ghildyal, N.P., Lonsane, B. K., Sreekantiah, K. R. and Murthy, V. S. (1985). Economics of submerged and solid state fermentations for the production of amyloglucosidase. Journal of Food Science and Technology 22: 171-176.

[22]. Girish, H.V and S.Satish (2008). Antibacterial activity of important medicinal plants on human pathogenic bacteria - a comparative analysis. World Application of Science Journal 5(3): 267-271.

[23]. Goyal, P.R and Singh, K.P (2005). Evolvulus alsinoides Linn. A medicinal herb. International Journal of Mendelian 22(3-4): 124-125.

[24]. Gunaseelan, N. (2004). Biochemical methane potential of fruits and vegetable solid waste feedstocks. Biomass and Bioenergy 26: 389-399.

[25]. Hang, Y.D. and Woodams, E. E. (1995). Grape pomace: A novel substrate for microbial production of citric acid. Biotechnology Letter 7: 253-254.

[26]. Himmel, M.E., Ding, S. Y., Johnson, D. K. Adney, W. S., Nimlos, M. R., Brady, J. W. and Foust, T. D. (2007). Biomass recalcitrance: Engineering plants and enzymes for biofuels production. Science 315: 804-807.

[27]. Husain, M.D. and William, R. (2010). Status of banana cultivation and disease incidences in Malaysia. Crop Protection and Plant Quarantine Division, Department of Agriculture, Malaysia, pp: 60.

[28]. Iwu, M.M., Duncan, A.R and Okunji, C.O (1999). New antimicrobials of plant origin. In: perspectives on new crops and New uses. Janick,J (Ed.),ASHS Press,Alexandria. PP457-462

[29]. Johann, F.O., Herrera, T. and Couto, S. R. (2007). Saccharification of banana agro-waste by cellulolytic enzymes. Dyes Pigments 75: $32-37$.

[30]. Johann, F.O., Jose, L., Herrera, T. and Couto, S. R. G. (2006). Banana skin: A novel waste for laccase production by Trametes pubescens under solid-state conditions. Application to synthetic dye decolouration. Dyes Pigments 75: 32-37.

[31]. Joshi, S.S., Dhopeshwarkar, R., Jadhav, U., Jadhav, R. D'Souza, L. and Dixit, J. (2001). Continuous ethanol production by fermentation of waste banana peels using flocculating yeast. Indian Journal of Chemistry and Technology 8: 153-156. 
[32]. Karthikeyan, A. and Sivakumar, N. (2010). Citric acid production by Koji fermentation using banana peel as a novel substrate. Bioresource and Technology 101: 5552-5556.

[33]. Khare, S.K., Krishna, J. and Gandhi, A. P. (1995). Citric acid production from Okara (soy residue) by solid state fermentation. Bioresource and Technology 54: 323-325.

[34]. Kim, S. and Dale, B. E. (2004). Global potential bioethanol production from wasted crops and crop residues. Biomass and Bioenergy 26: 361-375.

[35]. Manikandan, K., Saravanan, V. and Viruthagiri, T. (2008). Kinatics studies on ethanol production from banana peel using mutant strain of Saccharomyces cerevisiae. Indian Journal of Biotechnology 7: 83-88.

[36]. Milala, M.A., Shehu, B. B., Zanna, H. and Omosioda, V. O. (2009). Degradation of agro-waste by cellulase from Aspergillus candidus. Asian Journal of Biotechnology 1: 51-56.

[37]. Mokbel, M., Saif, F. and Hashinaga, F. (2005). Antibacterial and antioxidant activities of banana (Musa, AAA cv. cavendish) fruits peel. Asian Journal of Biotechnology 2: 1-4

[38]. Morton, J. (1987). Fruits of warm climates. Durian 1: 287-291.

[39]. Murray, M.(1995). The healing power of herbs. Prima publishing Rocklin. 171pp.

[40]. Natarajan, D., J.S Britto, K., Srinivasan, N.Nagamurugan, C. Mohanasundari and G. Perumal. (2005). Antibacterial activity of Euphorbia fusiformis - a rare medicinal herb. Journal of Ethnopharmacology 102: 123-126.

[41]. Nibedita, S., Sumanta, K. G., Satarupa, B. and Kaustav, A. (2011). Bioethanol production from agricultural wastes: An overview of Renewable Energy 37: 19-27.

[42]. Nigam, J.N. (2002). Bioconversion of water hyacinth hemicelluloses acid hydrolysate to motor fuel ethanol by xylose-fermenting yeast. Journal of Biotechnology 97: 107-116.

[43]. Nirmala, B., Somayaji, D. and Khanna, S. (1996). Biomethanation of banana peel and pineapple waste. Bioresource and Technology 58: 73-76.

[44]. Noreen, R., Asghar, M., Asad, M. J. and Adedayo, O. (2002). Production of $\alpha$-amylase from banana peel by Bacillus subtilis. Pakistan Journal of Agricultural Science 39: 23-26.

[45]. Oberio, H.S., Vadlani, P. V., Saida, L. and Hughes, J. D. (2011). Ethanol production from banana peels using statistically optimized simultaneous saccharification and fermentation process. Waste Management 31: 1576-1585.

[46]. Odebiyi, O.O and Sofowora,E.A(1978) Phytochemical Screening of Nigerian medicinal plants part II. Lloydia 41(1): 234-235

[47]. Ogier, J.C., Ballerini, D., Leygue, J. P., Rigal, L. and Pourquie, J. (1999). Production d ethanol a partir de biomasse lignocellulosique. Oil Gas Science and Technology Revue de lIFP 54: 67-94.

[48]. Ogunkwe, C.E., Oguzie,.E., E., Unaegbu, C.O and Okolue, B.N (2004). Phytochemical screening on the leaves of Sansevieria trifasciata. Journal of Chemical Society of Nigeria 29(1): 26-29.

[49]. Omojasola, P.F. and Jilani, O. P. (2009). Cellulose production by Trichoderma longi, Aspergillus niger and saccharomyces cerevisae cultured on plantain peel. Research Journal of Microbiology 40: 67-74.

[50]. Pandey, A., Soccol, C, R., Nigam, P. and Soccol, V. T. (2000). Biotechnological potential of agro-industrial residues. I: Sugarcane Bagasse. Bioresource and Technology 74: 69-80.

[51]. Parveen, J., Olorunnisola, K., Saheed, L. and Zahangir, A. (2012). Bio-Valorization Potential of Banana Peels (Musa sapientum): An Overview of Asian Journal of Biotechnology 4: 1-14.

[52]. Ponnuswamy, V., Lekshmi, V. D. and Prakash, S. G. V. (2011). Bio-processing of banana peel for amylase production by Sp. Penicillium. Asian Journal of Biological Science 2: 257-264.

[53]. Ratule M.T., Osman, A., Saari, N. and Ahmad, S. H. (2007). Microstructure of peel cell wall and selected physic-chemical characteristics of Berangan banana (Musacv. Berangan [AAA]) ripened at high temperature. Asia Pacific Journal of Molecular Biology and Biotechnology 15: 8-13.

[54]. Ravi, S.N., Kiran, K. V. Shailaja, R., Saritha, K. and Naidu, N. V. (2011). Single cell protein production by Trichoderma harzanium using banana peel. Int. J. Microb. Res. 2: 78-81.

[55]. Shaista, K., Asghar, M. Rehman, K., Asad, M. J. and Adedyo, O. (2003). Bio-Processing of banana peel for $\alpha$-amylase production by Bacillus subtilis. International Journal of Agriculture and Biology 5: 1560-8530.

[56]. Singh, A. (2008) Review of Ethnomedicinal uses and pharmacology of Evolvulus alsinoides Linn. Ethnobotanical leaflets 12: 734-740

[57]. Singh, B and Bhat, T.K (2003) Potential therapeutic applications of some antinutritional plant secondary metabolites. Journal of Agriculture and Food Chemistry 51: 5579-5597

[58]. Singh, I. and V.P, Singh (2000) Antifungal properties of aqueous and organic solution extracts of seed plants against Aspergillus flavus and A.niger. Phytomorphology 50: 151-157.

[59]. Thomas H. E., Rado, H.A., Bernard, W. J., Tchango, T. B. and Michel, P. (2007). Effects of the stage of maturation and varieties on the chemical composition of banana and plantain peels. Food Chemistry 103: 590-600.

[60]. Trease, G.E and W.C Evans (1996). Pharmacognosy. Macmillan publishers ltd. Pp 213-832.

[61]. Umoh, I.B. (1998). Commonly used Fruits in Nigeria. In: Nutrition Quality of Plant, Osagie, A.U. and O.U. Eka (Eds.). Foods Post Harvest Research Unit, University of Benin, Benin City, Nigeria, pp: 279 